\title{
INFLUENCE OF PREPARATION METHOD OF Spirogyra sp. ALGAE ON THEIR SORPTION CAPACITY
}

\author{
WPEYW SPOSOBU PREPAROWANIA PRÓBEK GLONÓW Spirogyra sp. \\ NA ICH POJEMNOŚĆ SORPCYJNĄ
}

\begin{abstract}
The influence of the preparation method of samples on the zinc ions sorption parameters in Spirogyra sp. algae was analysed. The $\mathrm{Zn}^{2+}$ sorption process from the salt solutions of this analyte was carried out in static conditions. The carried out analyses results show that the method of algae samples preparation for analyses (thermal drying, freeze drying, samples conditioning in demineralised water) and storage period influence their sorption capacity. On the basis of the carried out research of the metal sorption kinetics in live and prepared algae samples, it was found that the equilibrium is achieved after approximately $30 \mathrm{~min}$. In the experiment conditions, $56 \%$ of metals are sorbed in live algae during the first $15 \mathrm{~min}$. Approximately 17 and $65 \%$ of zinc ions present in the dilution accumulated in thermally dried and freeze dried algae samples respectively after 30 min of the process. It was confirmed that conditioning of the algae samples in demineralised water, prior to the sorption process, increases its efficiency. In order to define sorption capacity of freeze dried Spirogyra sp. algae, the Langmuir isotherm model was applied. It was found out that algae absorb heavy metals in proportion to their content in a solution, in which they were immersed. The sorption capacity of freeze dried Spirogyra sp. algae and zinc, defined with the use of the Langmuir isotherm, shows considerable imprecise result. Evident influence of hydrogen cations on zinc concentrations in algae and in the solution in the state of equilibrium was found out.
\end{abstract}

Keywords: zinc, the algae Spirogyra sp., preparation of the algae, the Langmuir isotherm model, sorption capacity

\section{Introduction}

The studies of heavy metals sorption processes both in dried and live algae have been carried out for many years. The objective of these studies was to assess the possibility to use algae biomass, eg in water fitoremediation [1-4], sewage treatment processes [5, 6] and in surface waters contamination biomonitoring [7-18].

The differences in sorption properties of different types of algae are emphasised, caused by physiological and morphological structure of thallus, the location of the sample taking and the method of algae preparation for the analysis [19]. The equilibrium and sorption process kinetics of algae are the most frequently measured parameters, eg [2].

\footnotetext{
${ }^{1}$ Chair of Biotechnology and Molecular Biology, Opole University, ul. kard. B. Kominka 6, 45-032 Opole, Poland, tel. +48 7740160 42, fax +48 7740160 51, email: mrajfur@o2.pl
} 
The studies of heavy metals sorption kinetics show that the time necessary to achieve dynamic equilibrium depends on, among others, the types of algae and biomass shredding level. Biomass of sea algae Ecklonia maxima with thallus size of $1.2 \mathrm{~mm}$ achieved equilibrium during sorption of $\mathrm{Cu}, \mathrm{Pb}$ and $\mathrm{Cd}$ after approximately $60 \mathrm{~min}$, whereas when the shredded thallus was the size of $0.075 \mathrm{~mm}$, the equilibrium was achieved after approximately $10 \mathrm{~min}$ [20]. It was found out that cosmopolitan algae Chlorella vullgaris and fresh water Scenedesmus quadricauda absorb 90-95\% of $\mathrm{Cu}$ during the first 15 min of the experiment (equilibrium was achieved after approximately 2 h) [21], sea algae Padina sp. absorb $90 \%$ of $\mathrm{Cd}$ during $35 \mathrm{~min}$ (equilibrium was achieved after approximately $60 \mathrm{~min})[22]$.

Considerable differences have been registered in the case of assessing algae sorption capacity. For example, the defined values of sorption capacity of two algae types: Cladophora glomerata and Spirogyra sp. in reference to copper ions are respectively $15.0 \mathrm{mg} \mathrm{g}^{-1}$ d.m. [23] and $133.3 \mathrm{mg} \mathrm{g}^{-1}$ d.m. (d.m. - dry mass) [2]. It seems that, aside from the variety of types, the main factors are the method of algae preparation, experiment conditions and the interpretation method of the studies results.

Various models, among other isotherm models by Freundlich [24, 25], Langmuir [26-28], Redlich-Peterson [1] and Koble-Corrigan [1] are used to describe the equilibrium status of the heavy metals sorption process in algae. The models are the basis for defining, among others, the sorption capacity of algae and the affinity levels of metals and algae thallus. Frequently, the best correlations between individual experimental and calculation data is obtained by the use of the Langmuir isotherm model [29-31].

The results of laboratory studies of kinetics and equilibrium of heavy metals in algae in static conditions have been obtained from numerous algae types, prepared in different ways to the analyses. These results are quite controversial, as there is no reliable methodology for preparing biomass to the tests. It is hard to specify whether the observed differences in sorption parameters result from the algae preparation method or their sorption characteristics.

The objective of the carried out studies was to assess the influence of preparation method and storage time of fresh water Spirogyra sp. algae samples on their sorption capacity, versus $\mathrm{Zn}^{2+}$ ions. The method of preparation of algae to analysis was optimised, in order to receive the samples with sorption characteristics comparable to live algae.

In order to define sorption capacity of freeze dried Spirogyra sp. algae, the Langmuir isotherm model was applied. The unreliability of measurements was assessed at the analysis and interpretation of the tests results stage.

\section{Experimental}

Spirogyra sp. algae from the Large Turawa Lake located in the south-western Poland (PL) were used for the tests. Algae samples were cleaned from biological impurities by rinsing with demineralised water. Cleaned samples were tested or further prepared. Concentration of zinc naturally present in the algae: $c_{(a, 0)}$, amounted to: $c_{\text {Zn(a,o) }}=0.021 \pm 0.002 \mathrm{mg} \mathrm{g}^{-1} \mathrm{~d} . \mathrm{m}$. 


\section{The research method}

The research was carried out on live and prepared algae. The research on the live algae was carried out immediately after cleaning. The algae were freeze dried at the temperature of $223 \mathrm{~K}$ for $20 \mathrm{~h}$ and by water evaporation at the temperature of $323 \mathrm{~K}(24 \mathrm{~h})$ and $353 \mathrm{~K}$ (12 h).

The algae samples with mass of approximately $0.50 \pm 0.02 \mathrm{~g} \mathrm{~d}$.m. were placed in a perforated container of approximately $15 \mathrm{~cm}^{3}$ capacity and immersed in $200 \mathrm{~cm}^{3}$ of zinc salt solution. Dried algae were immersed for $30 \mathrm{~min}$ in demineralised water, prior to experiment. The solution was thoroughly mixed by a magnetic agitator. The solution was regularly taken from the container in order to determine zinc concentration (AAS). The process was carried out for $40 \mathrm{~min}$.

Conductivity and $\mathrm{pH}$ values were measured during the zinc sorption process in algae biomass.

The research of equilibrium parameters in a static system was carried out parallel to the process kinetics research. The process was carried out with freeze dried algae and only the initial zinc ions concentrations were altered.

\section{Equipment and reagents}

The absorbing atomic spectroscope iCE 3000, made by Thermo Electron Corporation, USA, was used to determine zinc. For zinc, the detection $(I D L)$ and determination $(I Q L)$ limits of the equipment are, respectively, 0.0033 and $0.010 \mathrm{mg} \mathrm{dm}^{-3}$. The highest concentration of the model (made by: ANALYTIKA Ltd. (CZ)) used for calibration $\left(5 \mathrm{mg} \mathrm{dm}^{-3}\right)$ was assumed as the limit of the linear dependence of the signal from the concentration.

The conductivity and $\mathrm{pH}$ of the solutions, in which algae were immersed, were measured with the equipment made by Elmetron Sp.j. from Zabrze (PL): pH meter CP551 and conductivity meter CC551, which absolute measurement error was $\Delta \mathrm{pH}=0.02$ and $\Delta \kappa=0.1 \mu \mathrm{S} \mathrm{cm}^{-1}$, respectively.

MERCK reagents were used to prepare the solutions.

\section{Quality control}

The quality control of measurements was assured by test analyses of the BCR 414 plankton and BCR-482 lichen reference materials from the Institute for Reference Materials and Measurements in Belgium. The obtained results are summarized in Table 1.

Table 1

Measured and certified values of Zn concentration in the BCR 414 plankton and BCR 482 lichen reference material

\begin{tabular}{|c|c|c|c|c|c|c|c|c|c|}
\hline \multicolumn{5}{|c|}{ BCR 414 plankton } & \multicolumn{5}{|c|}{ BCR 482 lichen } \\
\hline \multirow{2}{*}{$\begin{array}{c}\text { Certified } \\
\text { value }\end{array}$} & \multirow{2}{*}{ \pm Uncertainty } & \multicolumn{2}{|c|}{ AAS } & \multirow{2}{*}{$D *$} & \multirow{2}{*}{$\begin{array}{c}\text { Certified } \\
\text { value }\end{array}$} & \multirow{2}{*}{ \pm Uncertainty } & \multicolumn{2}{|c|}{ AAS } & \multirow{2}{*}{$D *$} \\
\hline & & Mean & $\pm S D$ & & & & Mean & $\pm S D$ & \\
\hline \multicolumn{4}{|c|}{$\left[\mathrm{mg} \mathrm{kg}^{-1}\right.$ d.m.] } & {$[\%]$} & \multicolumn{4}{|c|}{$\left[\mathrm{mg} \mathrm{kg}^{-1}\right.$ d.m.] } & {$[\%]$} \\
\hline 112 & 3 & 103 & 4 & -8.0 & 100.6 & 2.2 & 93.9 & 2.5 & -6.7 \\
\hline
\end{tabular}

* Deviation - a difference between a measured value and a certified value, divided by the certified value 


\section{Biosorption isotherm model}

The Langmuir isotherms model is valid for monolayer adsorption on to surface containing finite number of identical sorption sites which is described by the following equation [31]:

$$
c_{(\mathrm{a}, 1)}=\left(c_{(\mathrm{a}, \max )} \cdot K \cdot c_{(\mathrm{s}, 1)}\right) \cdot\left(1+K \cdot c_{(\mathrm{s}, 1)}\right)^{-1}
$$

where: $c_{(\mathrm{a}, 1)}$ - equilibrium concentration of a given metal in algae [mmol g ${ }^{-1}$ d.m.], $c_{(\mathrm{s}, 1)}$ - equilibrium concentration of this metal ions in solution [mmol $\left.\mathrm{dm}^{-3}\right], c_{(\mathrm{a}, \max )}$ - sorption capacity of algae [mmol g ${ }^{-1}$ d.m.], $K$ - constant.

The Langmuir equation can be rearranged to linear form for the convenience of plotting and determining the Langmuir constants as below:

$$
\left(c_{(\mathrm{a}, 1)}\right)^{-1}=\left(c_{(\mathrm{a}, \max )} \cdot K \cdot c_{(\mathrm{s}, 1)}\right)^{-1}+\left(c_{(\mathrm{a}, \max )}\right)^{-1}
$$

\section{Results and discussion}

The research of zinc ions sorption by Spirogyra sp. algae was carried out in two stages, applying the methodology referred to in the previous chapter. During the first stage, the sorption process' kinetics was analysed, using live and prepared algae. The influence of the algae preparation methods on their sorption capacity was assessed. The second stage included research of equilibrium parameters, defined by the Langmuir isotherm model.

\section{The influence of algae samples preparation method on zinc sorption kinetics}

The kinetics research was carried out in static conditions, in order to estimate the time required to achieve equilibrium between the algae and the solution, in which they were immersed.

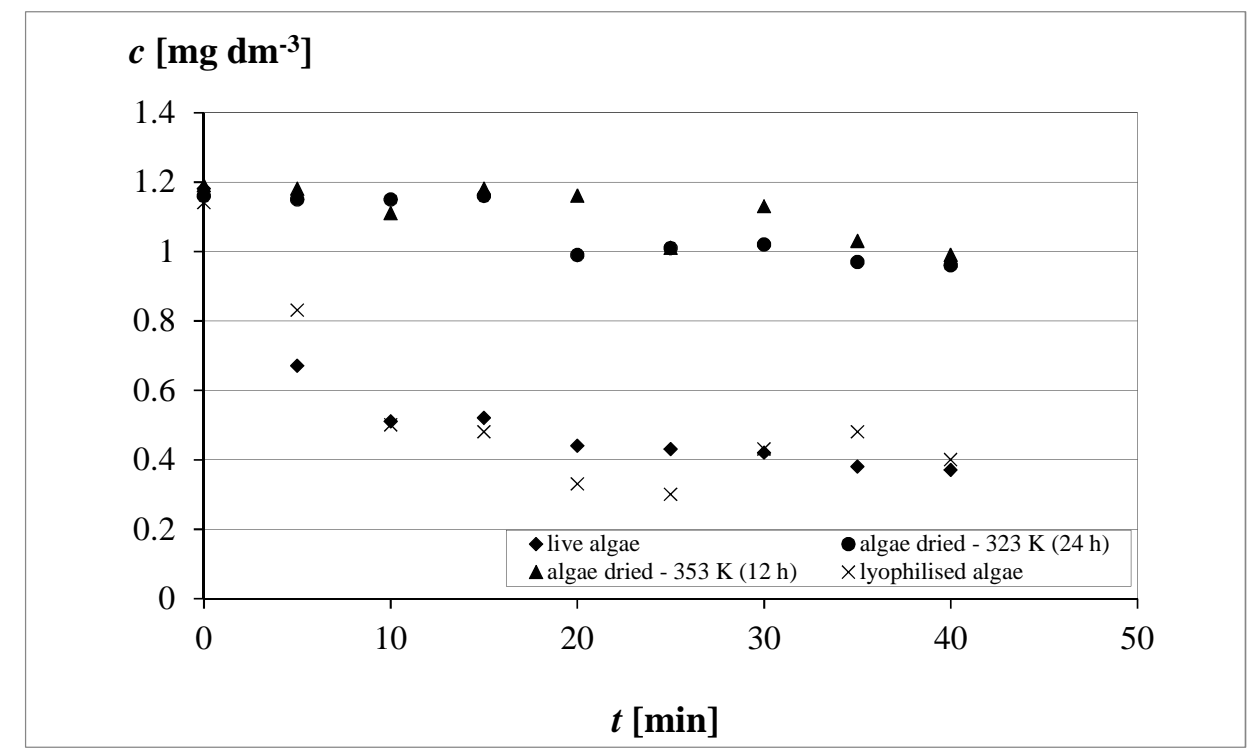

Fig. 1. Changes of $\mathrm{Zn}$ concentration in the solution, in which live and prepared Spirogyra sp. algae were immersed 
Figure 1 presents examples of $\mathrm{Zn}$ concentration changes in the solution, in which algae were immersed. The process parameters: the solution initial concentration $c_{\mathrm{Zn}, 0}=1.14 \pm 0.05 \mathrm{mg} \mathrm{dm}^{-3}$, live algae wet mass approximately $8.0 \mathrm{~g}$, after drying $0.50 \pm 0.02 \mathrm{~g}$, dry mass of prepared algae $0.50 \pm 0.02 \mathrm{~g}$.

The results of the carried out research show that the dynamic equilibrium during zinc sorption in Spirogyra sp. algae, both live and prepared, is achieved after approximately 30 min. During that time, approximately $69 \%$ of $\mathrm{Zn}^{2+}$ ions, present in initial solution, accumulate in live algae samples. During the first $15 \mathrm{~min}$ of the process, approximately $56 \%$ pf $\mathrm{Zn}^{2+}$ ions is absorbed from the solution to biomass, in reference to their concentration accumulated in algae in equilibrium (for $\mathrm{Zn}-0.27 \mathrm{mg} \mathrm{g}^{-1} \mathrm{~d} . \mathrm{m}$ ). In the prepared algae samples, compared to live algae, after $30 \mathrm{~min}$ of the process the following amounts accumulated respectively: the algae dried at $323 \mathrm{~K}$ - approximately $17 \%$, the algae dried at $353 \mathrm{~K}$ - approximately $17 \%$, the algae freeze dried - approximately $65 \%$ of zinc ions.

In order to increase $\mathrm{Zn}^{2+}$ sorption efficiency in thermally and freeze dried Spirogyra sp. algae, the biomass samples were prepared for $30 \mathrm{~min}$ in demineralised water, with conductivity of $\Delta \kappa=0.5 \mu \mathrm{S} \mathrm{cm}$. The graphs in Figure 2 show changes of zinc concentration in the solution, in which the prepared algae were immersed, and additionally activated in demineralised water.

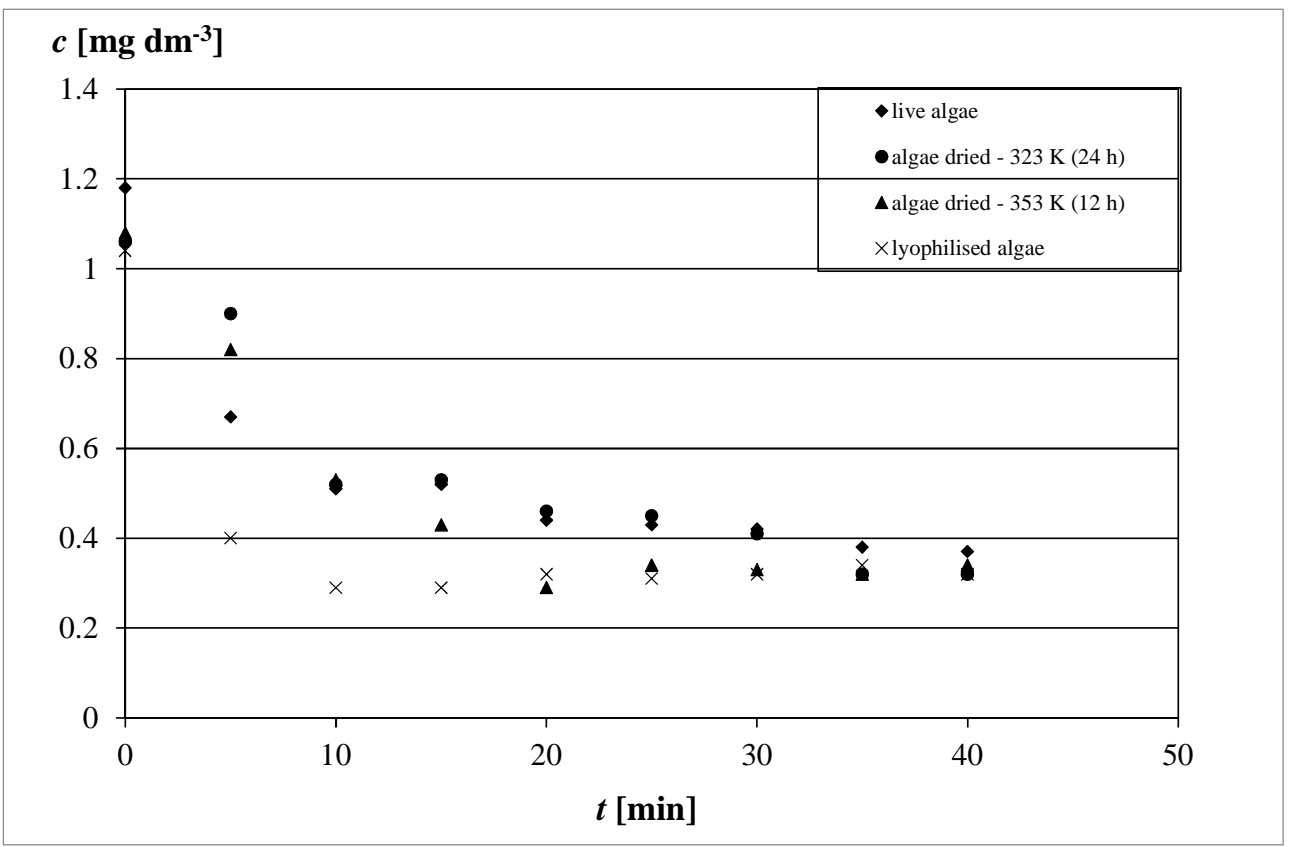

Fig. 2. Changes of $\mathrm{Zn}$ concentration in the solution, in which live and prepared Spirogyra sp. algae were immersed, activated in demineralised water

The results presented in the graph show that the prepared algae, in order to achieve the proper sorption parameters, should be immersed for approximately $30 \mathrm{~min}$ in demineralised water; then their sorption characteristics are comparable to those of live algae. 
The graphs in Figures 3 and 4 present respectively the changes of conductivity during $\mathrm{Zn}$ sorption process, in live and prepared algae biomass.

\section{$\kappa\left[\mu \mathrm{S} \mathrm{cm}^{-1}\right]$}

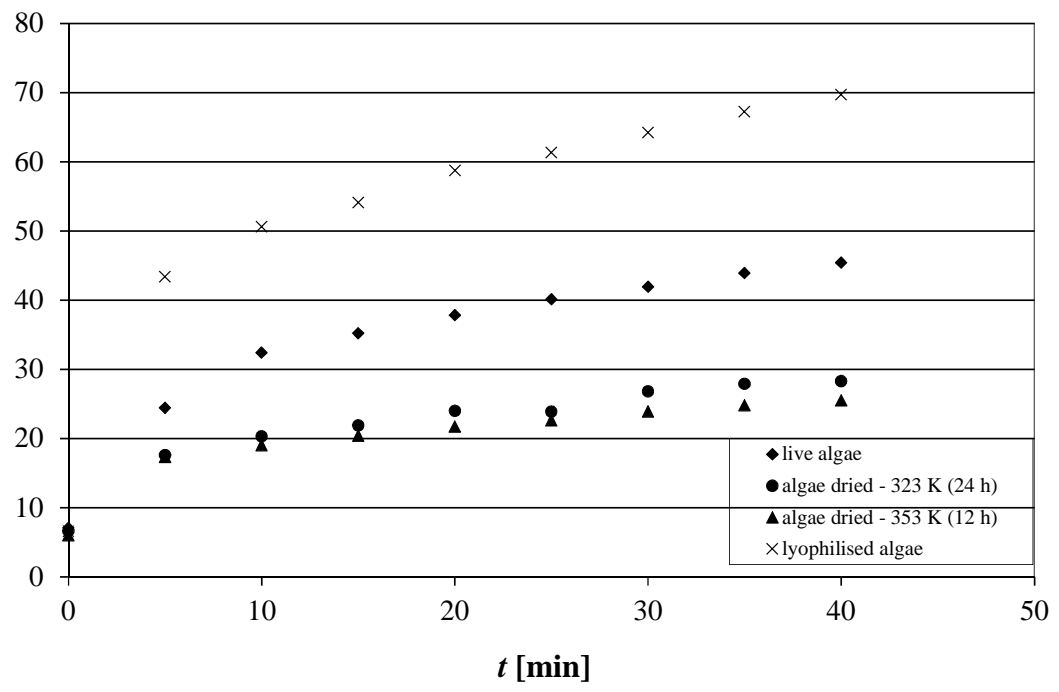

Fig. 3. Changes of conductivity in $\mathrm{Zn}$ solution, in which live and prepared algae were immersed, activated in demineralised water

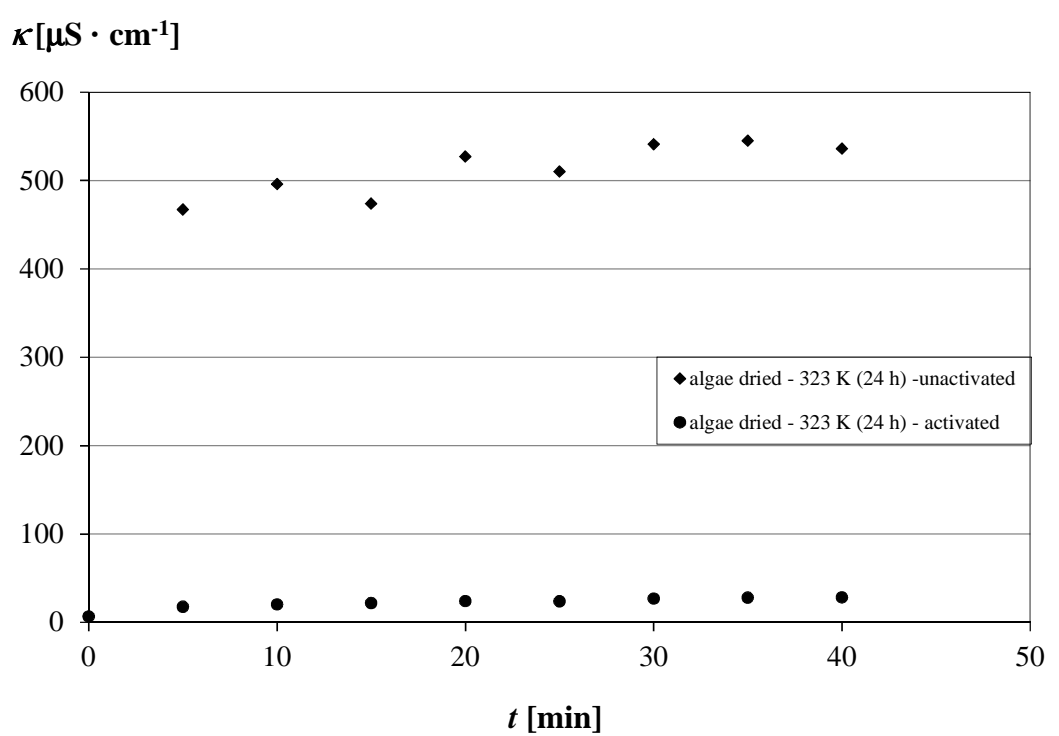

Fig. 4. Comparison of conductivity changes in zinc solutions, in which the prepared algae were immersed 
During the zinc sorption process in Spirogyra sp., increase of conductivity was recorded (Fig. 3). It can be assumed that it was caused by the progressive and irreversible changes in the cellular membranes structure, which results in ions leaking from algae cells to the solution. This effect was observed during the tests of the influence of copper on lichens thallus. Potassium ions were released to the solution, in consequence of cells membrane destruction [32]. It was determined that (Fig. 4) conductivity of the solutions, to which the samples of algae not activated in demineralised water were introduced, was approximately 10 times higher than conductivity of the solution, in which the biomass previously conditioned in demineralised water was immersed. The presence in the solution of a large number of sodium, potassium, calcium and manganese ions introduced with an algae sample could have been the reason for the reduced sorption of metal ions.

The graphs presented in Figure 5 show that the process of $\mathrm{Zn}^{2+}$ ions sorption by algae biomass is accompanied by the sorption of $\mathrm{H}^{+}$ions. This conclusion is confirmed by the tests of heavy metals sorption kinetics from the solutions with $\mathrm{pH}=3.5$.

$0.1 \mathrm{M}$ of hydrochloric acid was added in order to reduce $\mathrm{pH}$ of the zinc salt solution. Figure 6 presents the graph with results of the carried out analyses.

It was determined that the higher $\mathrm{H}^{+}$ions concentration in the solution, into which algae were added, the higher their competitiveness versus metal ions. From the solution with the initial $\mathrm{pH}=4.10$ and metal concentration $c_{\mathrm{Zn}, 0}=1.10 \mathrm{mg} \mathrm{dm}^{-3}$, more $\mathrm{Zn}^{2+}$ ions were absorbed ( $0.31 \mathrm{mg} \mathrm{g}^{-1}$ d.m.) than from the solution with the same zinc concentration and $\mathrm{pH}=3.50\left(0.23 \mathrm{mg} \mathrm{g}^{-1} \mathrm{~d}\right.$.m.). This conclusion is confirmed by the result of the research carried out by other authors [33].

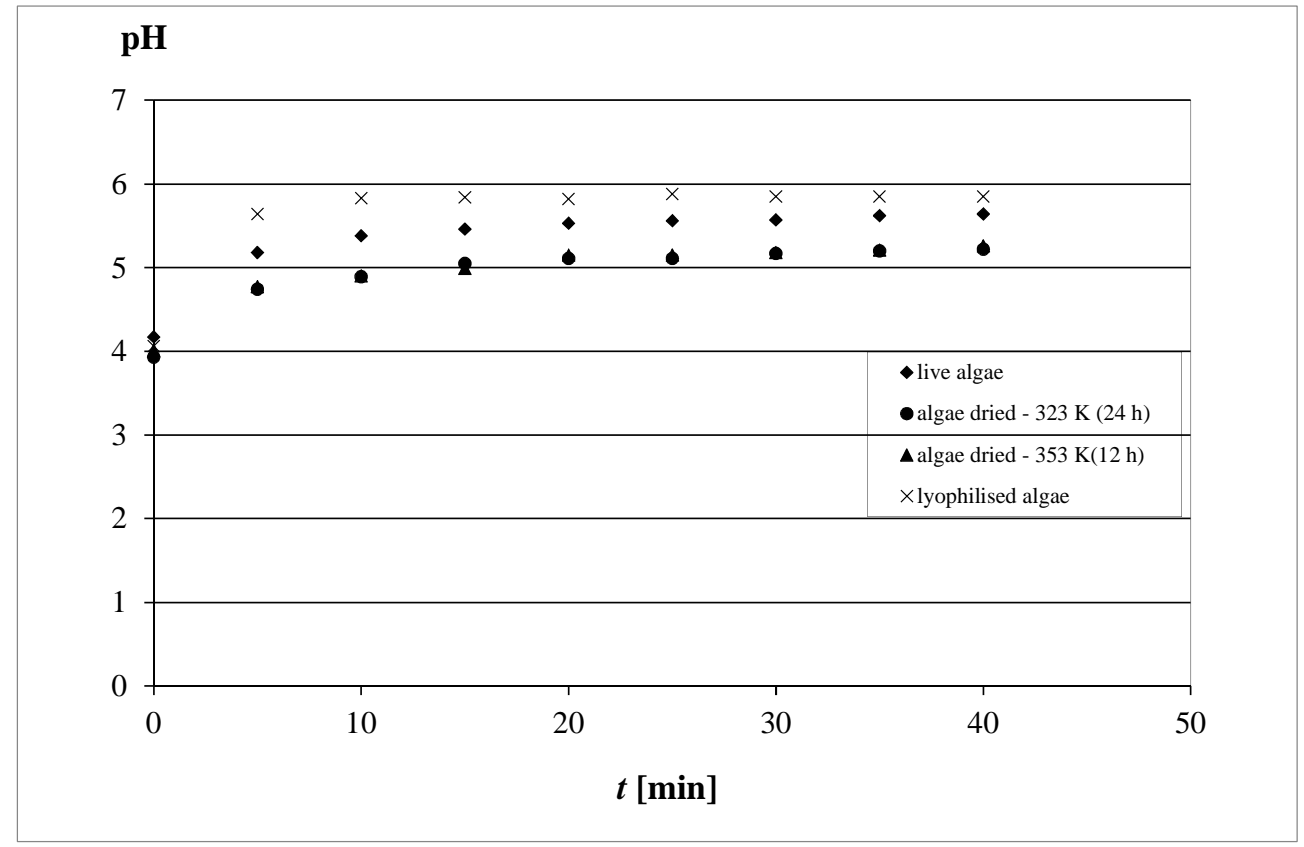

Fig. 5. Changes of $\mathrm{H}^{+}$ions concentration in zinc solution, in which live and prepared algae were immersed, activated in demineralised water 


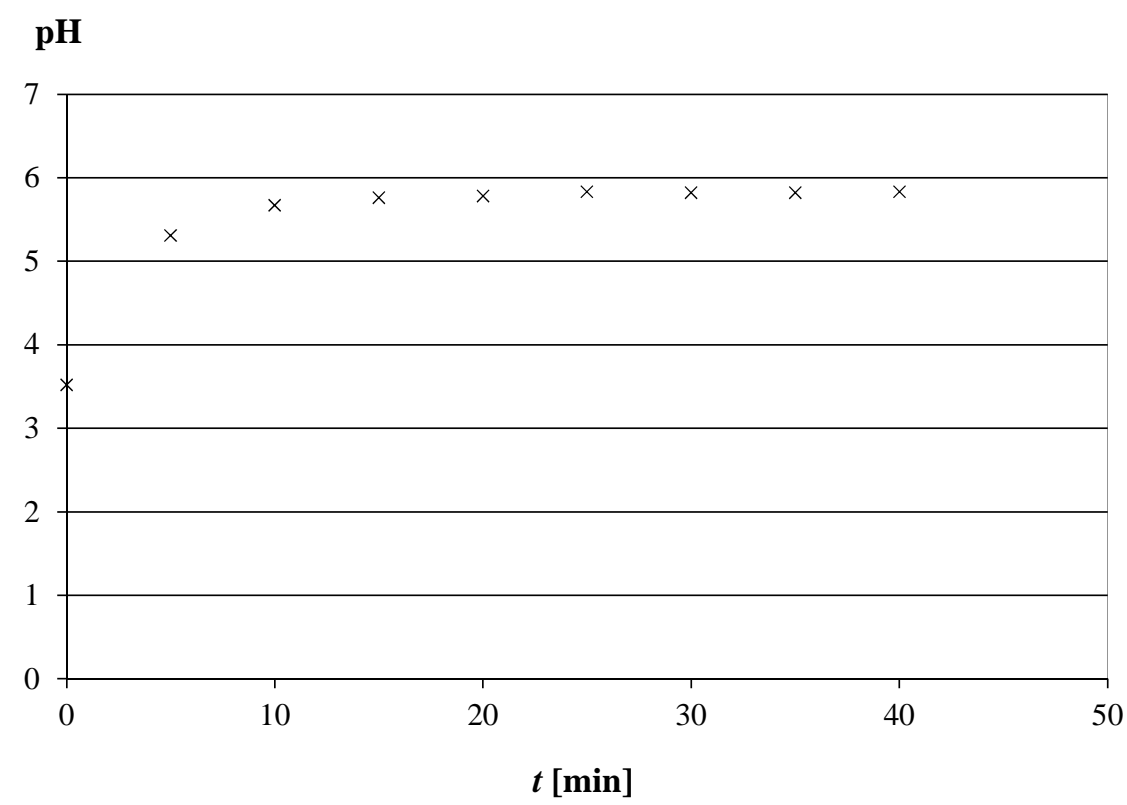

Fig. 6. Changes of $\mathrm{H}^{+}$ions concentration in zinc solution with $\mathrm{pH}=3.5$, in which the freeze dried Spirogyra sp. algae were immersed

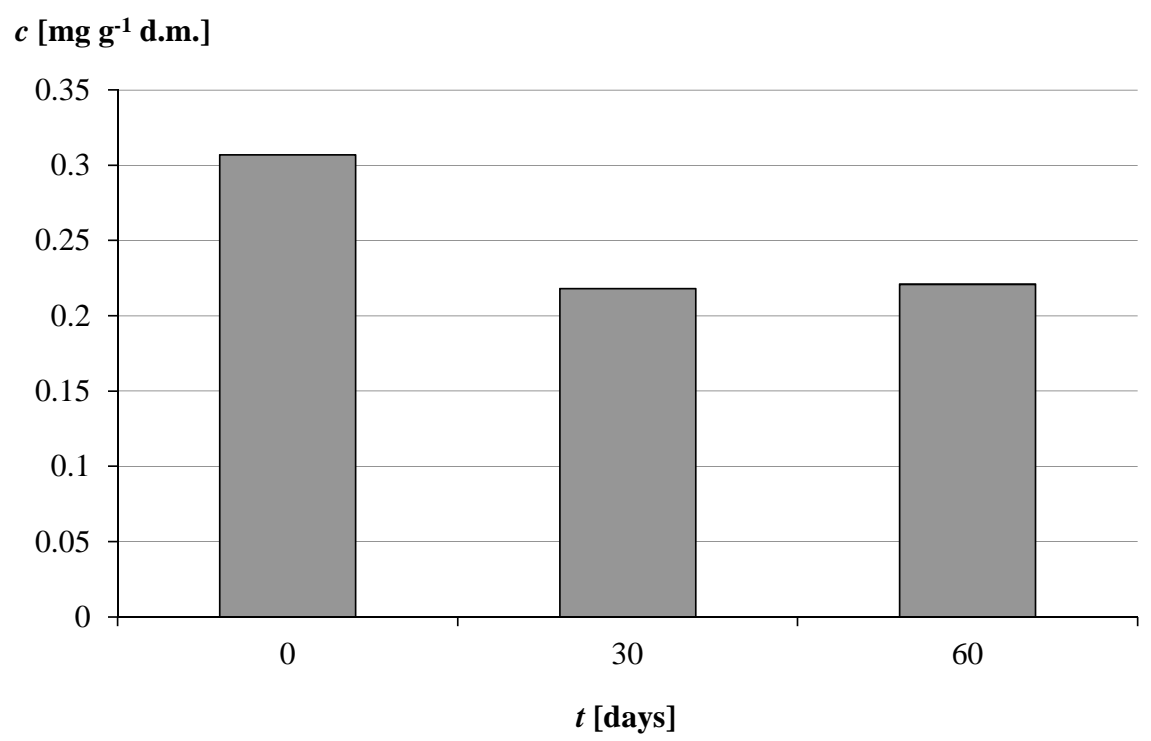

Fig. 7. Zinc concentration in freeze dried algae samples, depending on the storage period 
The influence of algae samples storage period on zinc sorption was also analysed. The biomass samples for analyses were stored in a tightly closed polyethylene container. The graph in Figure 7 shows the values of zinc concentration accumulated in algae, which were prepared for analysis, after 30 and 60 days form the collection.

It was found out that the algae sorption qualities changed after 30 days of storage. Approximately 29\% less zinc ions accumulated in biomass samples, in comparison to the samples used for analyses directly after freeze drying. Extension of algae storage period up to 60 days did not cause any further changes. It can be assumed that the observed changes in algae sorption capacity are the result of chemical decomposition of the algae structures, destroyed during the freeze drying process.

\section{Assessment of sorption capacity of freeze dried Spirogyra sp.}

The next stage included analyses of equilibria during $\mathrm{Zn}^{2+}$ ions sorption from its salt solutions and assessment of sorption capacity of freeze dried Spirogyra sp.

On the basis of measurements of heavy metals concentrations in the solution $c_{(s)}$, before $(0)$ and after (1) sorption process, metals concentrations were determined $c_{(a)}$, converted to $1 \mathrm{~g}$ d.m. (dry mass of the algae). In order to maintain the experiment conditions $(0.5 \mathrm{~g}$ d.m. of algae introduced to $200 \mathrm{~cm}^{3}$ of metals salts solution), it should be assumed that sorption in $1 \mathrm{~g} \mathrm{~d} . \mathrm{m}$. of algae is carried out from $400 \mathrm{~cm}^{3}$ of the solution. The change of the sorbent mass in comparison to the solution volume in static conditions influences the equilibrium status.

The results calculated according to correlation (2) are presented in Figure 8.

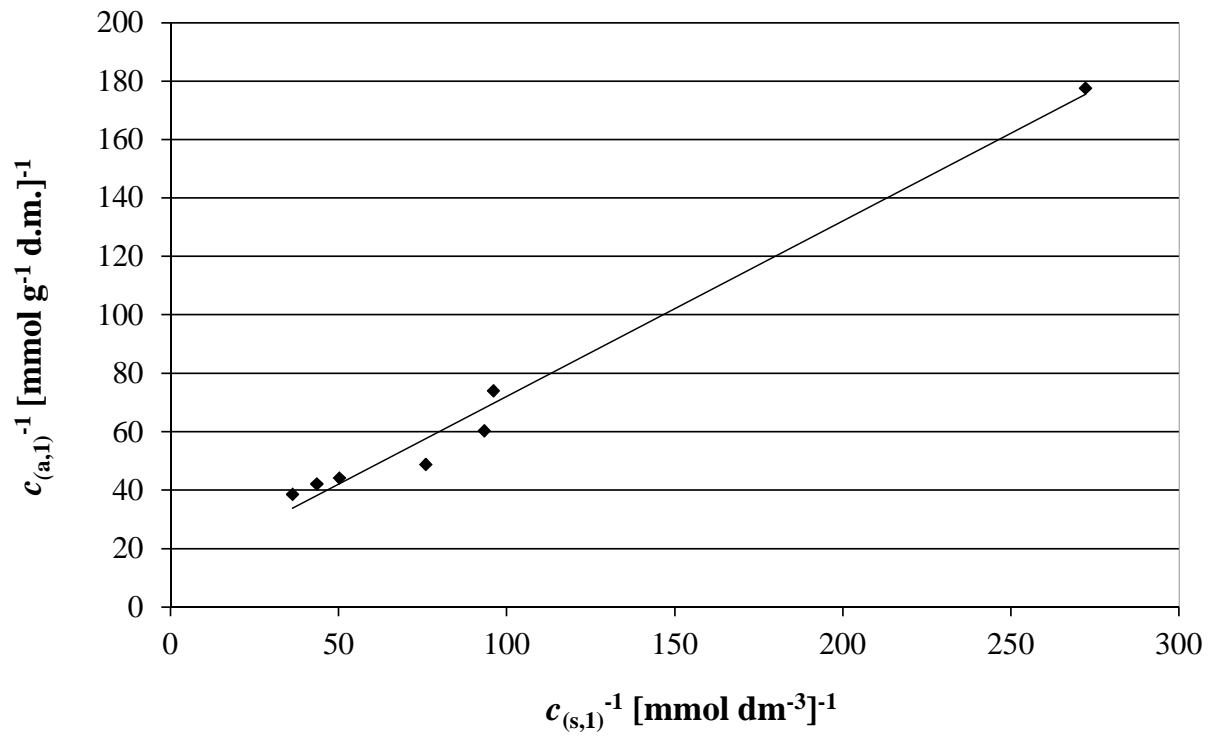

Fig. 8. The Langmuir isotherm describing sorption equilibrium $\mathrm{Zn}\left(t_{\text {sorption }}=30 \mathrm{~min}\right)$ 
The Langmuir isotherms parameters are presented in Table 2.

Table 2

Function $y=a \cdot x+b$ parameters presented in Figure 8; linear regression parameters: $\pm S D_{a}$ - standard deviation of the parameter $a, \pm S D_{b}$ - standard deviation of the parameter $b, R^{2}$ - correlation coefficient and $c_{(a, \max )}$ - sorption capacity

\begin{tabular}{|c|c|c|c|c|c|}
\hline \multicolumn{6}{|c|}{ The Langmuir isotherm model } \\
\hline$a$ & $b$ & $\pm S D_{a}$ & $\pm S D_{b}$ & $R^{2}$ & $c_{(a, \max )}\left[\mathrm{mmol} \mathrm{g}^{-1}\right.$ d.m. $]$ \\
\hline 0.600 & 12.1 & 0.032 & 3.88 & 0.986 & 0.083 \\
\hline
\end{tabular}

On the basis of the carried out research, it was determined that the analysed algae absorb zinc in proportion to its content in the solution. The Langmuir isotherm model is well adjusted $\left(R^{2}=0.986\right)$ to the experiment data. Little value $\pm S D_{a}=0.032$ of the $a$ parameter of the Langmuir isotherm shows the linear correlation of zinc concentration in algae and its content in a solution. The defined by Langmuir isotherm sorption capacities $c_{(a, \max )}=0.083 \mathrm{mmol} / \mathrm{g} \mathrm{d} . \mathrm{m}$. is a reference value only, because it is highly unreliable, expressed by $\pm S D_{b}$. One may assume that one of the causes of wide distribution of measuring points, versus the theoretical straight line defined by the Langmuir isotherm (Fig. 8), is the competitive sorption of hydrogen cations [34]. Therefore, in order to determine sorption capacity of algae, one should consider the sum of absorbed hydrogen and zinc cations.

In order to perform detailed comparison of equilibria parameters of two valence zinc cations and one valence hydrogen cations, their concentrations were expressed as: $c^{*}=z \cdot c$, where $z$ - cation valence (nondimensional number), $c$ - concentration expressed in mmol $\mathrm{dm}^{-3}$ or mmol $\mathrm{g}^{-1}$. Table 3 contains a summary of concentrations $c^{*}$ of zinc cations in solutions $(s)$ and in algae $(a)$ before $(0)$ and after $(1)$ sorption process, and concentrations $c^{*}$ of hydrogen ions in solutions $(s)$ and in algae $(a)$ after $(1)$ sorption process. The initial concentrations of $\mathrm{H}^{+}$and $\mathrm{Zn}^{2+}$ in algae were assumed as equal to zero.

Table 3

Zinc concentrations in dry mass of algae and solutions before and after sorption process and hydrogen ions concentration in solutions and algae after sorption process

\begin{tabular}{|c|c|c|c|c|c|}
\hline \multirow{2}{*}{$\begin{array}{c}\text { Measurement } \\
\text { series }\end{array}$} & $c^{*} Z n(s, 0)$ & $c^{*} Z n(s, 1)$ & $c^{*} Z n(a, 1)$ & $c^{*} H(s, 1)$ & $c^{*} H(a, 1)$ \\
\hline & {$\left[\mathrm{mmol} \mathrm{dm}^{-3}\right]$} & {$\left[\mathrm{mmol} \mathrm{dm}^{-3}\right]$} & {$\left[\mathrm{mmol} \mathrm{g}^{-1}\right]$} & {$\left[\mathrm{mmol} \mathrm{dm}^{-3}\right]$} & {$\left[\mathrm{mmol} \mathrm{g}^{-1}\right]$} \\
\hline 1 & 0.0318 & 0.0037 & 0.0056 & 0.0014 & 0.0047 \\
\hline 2 & 0.0781 & 0.0104 & 0.0135 & 0.0019 & 0.0059 \\
\hline 3 & 0.0937 & 0.0107 & 0.0166 & 0.0009 & 0.0048 \\
\hline 4 & 0.1157 & 0.0132 & 0.0205 & 0.0015 & 0.0045 \\
\hline 5 & 0.1332 & 0.0199 & 0.0226 & 0.0019 & 0.0053 \\
\hline 6 & 0.1417 & 0.0229 & 0.0238 & 0.0013 & 0.0061 \\
\hline 7 & 0.1573 & 0.0275 & 0.0259 & 0.0011 & 0.0054 \\
\hline
\end{tabular}

Figure 9 presents the Langmuir isotherm determined pursuant to correlation (2), for the sum of cations $\mathrm{H}^{+}$and $\mathrm{Zn}^{2+}$. 


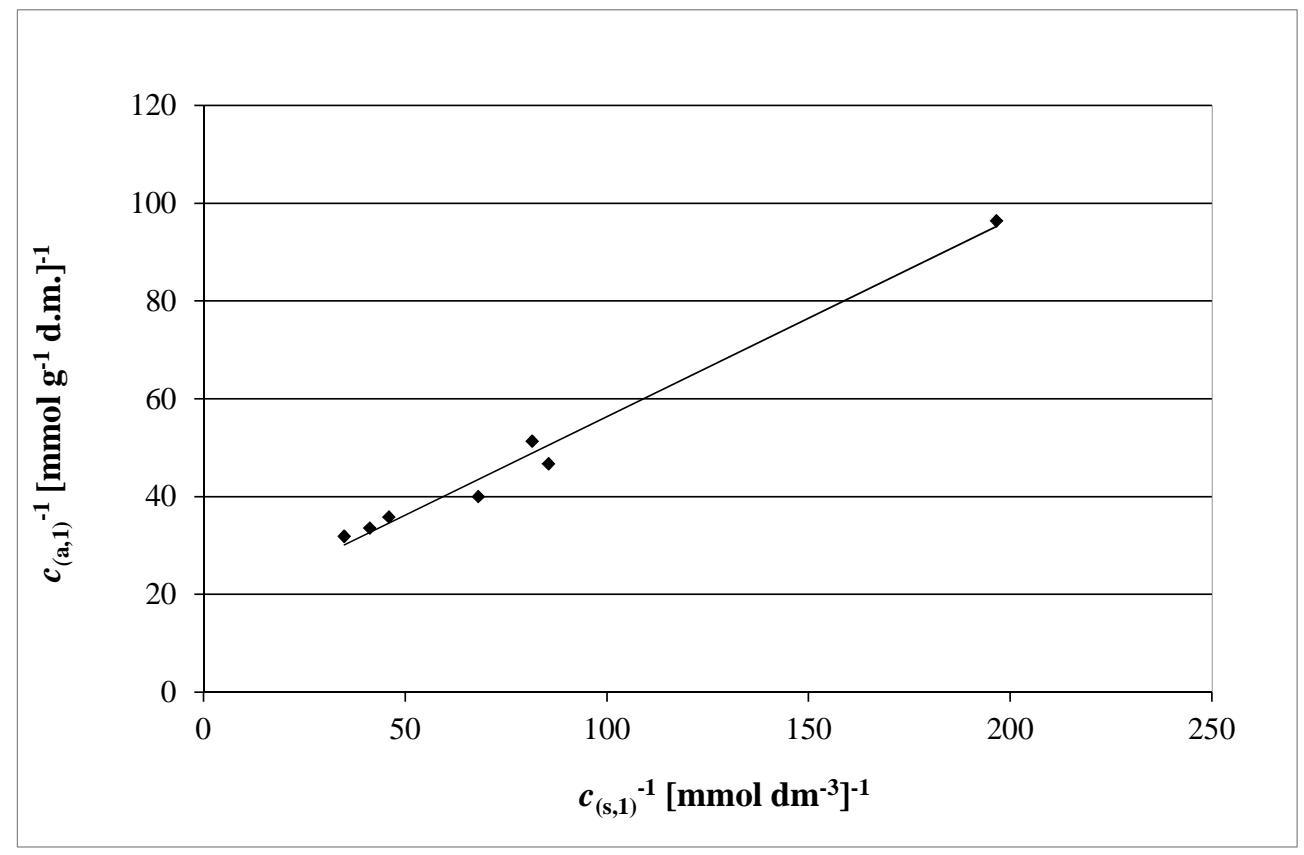

Fig. 9. The Langmuir isotherm determined for the sum of cations $\mathrm{H}^{+}$and $\mathrm{Zn}^{2+}$

The parameters for the Langmuir isotherm determined for the sum of cations $\mathrm{H}^{+}$and $\mathrm{Zn}^{2+}$ are presented in Table 4 .

Table 4

Function $y=a \cdot x+b$ parameters presented in Figure 9; linear regression parameters: $\pm S D_{a}$ - standard deviation of the parameter $a, \pm S D_{b}$ - standard deviation of the parameter $b, R^{2}$ - correlation coefficient and $c_{(a, \max )}$ - sorption capacity

\begin{tabular}{|c|c|c|c|c|c|}
\hline \multicolumn{6}{|c|}{ The Langmuir isotherm model } \\
\hline$a$ & $b$ & $\pm S D_{a}$ & $\pm S D_{b}$ & $R^{2}$ & $c_{(a, \max )}\left[\mathrm{mmol} \mathrm{g}^{-1}\right.$ d.m. $]$ \\
\hline 0.403 & 16.1 & 0.019 & 1.89 & 0.987 & 0.062 \\
\hline
\end{tabular}

The Spirogyra sp. algae sorption capacity, determined from the Langmuir isotherm for zinc, amounts to: $c^{*}=0.083 \mathrm{mmol} \mathrm{g}^{-1}\left(2.72 \mathrm{mg} \mathrm{g}^{-1}\right.$ of algae dry mass), and with reference to the sum of $\mathrm{H}^{+}$and $\mathrm{Zn}^{2+}$ amounts to: $c^{*}=0.062 \mathrm{mmol} \mathrm{g}{ }^{-1}\left(2.03 \mathrm{mg} \mathrm{g}^{-1}\right.$ d.m.). The carried out research showed that, in reference to the sum of cations, unreliability of assessment of sorption capacity of freeze dried Spirogyra sp. algae is expressed by $\pm S D_{b}=1.89$. These results show that the assessment of sorption capacity determined for zinc, carries a $50 \%$ greater error than the one determined for the sum of cations.

The carried out research results analysis shows that the differences in assessment of sorption capacity of different algae types may result from, among others, differences in sorption characteristics of different types of algae, the samples preparation methods as well as the selection of an appropriate model for the research results interpretation. 


\section{Conclusions}

On the basis of the carried out research, it was determined that the fresh water Spirogyra sp. algae accumulate $\mathrm{Zn}^{2+}$ ions from the solutions they come in contact with. Biomass sorption characteristics are influenced by the algae preparation method and storage period. The Langmuir isotherm model can be used to describe correlations between zinc concentrations in algae and the solution. This model is well adjusted to the experiment data. However, the determined sorption capacity value is characterised by high unreliability, expressed by $\pm S D_{b}$. The unreliability of results regarding algae sorption capacity is influenced by the competitive sorption of $\mathrm{H}^{+}$ions. Therefore, in order to determine sorption capacity of algae, one should consider the sum of absorbed hydrogen and metal cations.

In order to validate the research procedures, the appropriate preparation and storage of algae samples methodology should be applied, as well as the relevant model of the research results interpretation. All the operations aim at obtaining the most reliable analyses results.

\section{Acknowledgements}

The Project received financial assistance from the funds of the National Science Centre granted by force of the decision no. DEC-2011/03/D/NZ9/00051.

\section{References}

[1] El-Sikaily A, El Nemr A, Khaled A, Abdelwehab O. Removal of toxic chromium from wastewater using green alga Ulva lactuca and its activated carbon. J Hazard Mater. 2007;148:216-228.

[2] Gupta VK, Rastogi A, Saini VK, Jain N. Biosorption of copper(II) from aqueous solutions by Spirogyra species. J Colloid and Interface Sci. 2006;296:59-63. DOI:10.1016/j.jcis.2005.08.033

[3] Mudhoo A, Garg VK, Wang S. Removal of heavy metals by biosorption. Environ Chem Lett. 2012;10:109-117.

[4] Yoshida N, Ikeda R, Okuno T. Identifcation and characterization of heavy metal-resistant unicellular alga isolated from soil and its potential for phytoremediation. Bioresour Technol. 2006;97:1843-1849. DOI: 10.1016/j.biortech.2005.08.021.

[5] Apiratikul R, Pavasant P. Batch and column studies of biosorption of heavy metals by Caulerpa lentillifera. Bioresour Technol. 2008;99:2766-2777. DOI:10.1016/j.biortech.2007.06.036

[6] Pavasant P, Apiratikul R, Sungkhum V, Suthiparinyanont P, Wattanachira S, Marhaba TF. Biosorption of $\mathrm{Cu}^{2+}, \mathrm{Cd}^{2+}, \mathrm{Pb}^{2+}$, and $\mathrm{Zn}^{2+}$ using dried marine green macroalga Caulerpa lentillifera. Bioresour Technol. 2006;97:2321-2329. DOI:10.1016/j.biortech.2005.10.032.

[7] Al-Shwafi NA, Rushdi AI. Heavy metal concentrations in marine green, brown, and red seaweeds from coastal waters of Yemen, the Gulf of Aden. Environ Geol. 2008;55:653-660. DOI: 10.1007/s00254-007-1015-0.

[8] Atici T, Ahiska S, Altindag A, Aydin D. Ecological effects of some heavy metals (Cd, $\mathrm{Pb}, \mathrm{Hg}, \mathrm{Cr}) \mathrm{pollution}$ of phytoplanktonic algae and zooplanktonic organisms in Sarıyar Dam Reservoir in Turkey. African J Biotechnol. 2008;7:1972-1977.

[9] Benkdad A, Laissaoui A, Tornero MV, Benmansour M, Chakir E, Garrido IM, et al. Trace metals and radionuclides in macroalgae from Moroccan coastal waters. Environ Monit and Assess. 2011;182:317-324. DOI 10.1007/s10661-011-1878-0.

[10] Conti ME, Cecchetti G. A biomonitoring study: trace metals in algae and molluscs from Tyrrhenian coastal areas. Environ Res. 2003;93:99-112.

[11] Giusti L. Heavy metal contamination of brown seaweed and sediments from the UK coastline between the Wear river and the Tees river. Environ Inter. 2001;26:275-286.

[12] Kamala-Kannan S, Prabhu Dass Batvari B, Jae Lee K, Kannan N, Krishnamoorthy R, Shanthi K, et al. Assessment of heavy metals $(\mathrm{Cd}, \mathrm{Cr}$ and $\mathrm{Pb})$ in water, sediment and seaweed (Ulva lactuca) in the Pulicat Lake, South East India. Chemosphere 2008;71:1233-1240. DOI: 10.1016/j.chemosphere.2007.12.004. 
[13] Kaonga CC, Chiotha SS, Monjerezi M, Fabiano E, Henry EM. Levels of cadmium, manganese and lead in water and algae; Spirogyra aequinoctialis. Inter J Environ Sci and Technol. 2008;5:471-478.

[14] Karadede-Akin H, Ünlü E. Heavy metal concentrations in water, sediment, fish and some benthic organisms from Tigris River, Turkey. Environ Monit and Assess. 2007;131:323-337. DOI: 10.1007/s10661-006-9478-0.

[15] Laib E, Leghouchi E. Cd, Cr, $\mathrm{Cu}, \mathrm{Pb}$, and $\mathrm{Zn}$ concentrations in Ulva lactuca, Codium fragile, Jania rubens, and Dictyota dichotomia from Rabta Bay, Jijel (Algeria). Environ Monit and Assess. 2012;184;1711-1718. DOI: $10.1007 / \mathrm{s} 10661-011-2072-0$.

[16] Melville F, Pulkownik A. Seasonal and spatial variation in the distribution of mangrove macroalgae in the Clyde River, Australia. Estuarine, Coastal and Shelf Science. 2007;71:683-690. DOI: 10.1016/j.ecss.2006.09.023.

[17] Strezov A, Nonova T. Environmental monitoring of heavy metals in Bulgarian Black Sea green algae. Environ Monit and Assess. 2005;105:99-110.

[18] Topcuoğlu S, Güven KC, Balkıs N, Kırbaşoğlu C. Heavy metal monitoring of marine algae from the Turkish Coast of the Black Sea, 1998-2000. Chemosphere. 2003;52:1683-1688.

[19] Pawlik-Skowrońska B. Tajemnice odporności glonów i sinic na toksyczne metale ciężkie [The algae in environments contaminated with heavy metals]. Kosmos. 2002;51:175-184.

[20] Feng D, Aldrich C. Adsorption of heavy metals by biomaterials derived from the marine alga Ecklonia maxima. Hydrometallurgy. 2004;73:1-10. DOI: 10.1016/S0304-386X(03)00138-5.

[21] Harris PO, Ramelow GJ. Binding of metal ions by particulate biomass derived from Chlorella vulgaris and Scenedesmus quadricauda. Environ Sci and Technol. 1990;24:220-228.

[22] Kaewsarn P, Yu Q. Cadmium(II) removal from aqueous solutions by pre-treated biomass of marine alga Padina sp. Environ Pollut. 2001;112:209-213.

[23] Yalçın E, Çavuşoğlu K, Maraş M, Bıyıkoğlu M. Biosorption of lead(II) and copper(II) metal ions on Cladophora glomerata (L.) Kütz. (Chlorophyta) algae: effect of algal surface modification. Acta Chimica Slovenica. 2008;55:228-232.

[24] Bulgariu D, Bulgariu L. Equilibrium and kinetics studies of heavy metal ions biosorption on green algae waste biomass. Bioresour Technol. 2012;103:489-493. DOI: 10.1016/j.biortech.2011.10.016.

[25] Tien CJ. Biosorption of metal ions by freshwater algae with different surface characteristics. Process Biochem. 2002;38:605-613. PII: S0032-9592(02)00183-8

[26] Ajjabi LCh, Chouba L. Biosorption of $\mathrm{Cu}^{2+}$ and $\mathrm{Zn}^{2+}$ from aqueous solutions by dried marine green macroalga Chaetomorpha linum. $J$ of Environ Manage. 2009;90:3485-3489. DOI: 10.1016/j.jenvman.2009.06.001.

[27] Ji L, Xie S, Feng J, Li Y, Chen L. Heavy metal uptake capacities by the common freshwater green alga Cladophora fracta. J Appl Phycol. 2012;24:979-983. DOI: 10.1007/s10811-011-9721-0.

[28] Lee Yi-Ch, Chang Sh-P. The biosorption of heavy metals from aqueous solution by Spirogyra and Cladophora filamentous macroalgae. Bioresour Technol. 2011;102:5297-5304. DOI: 10.1016/j.biortech.2010.12.103.

[29] Gupta VK, Rastogi A, Nayak A. Biosorption of nickel onto treated alga (Oedogonium hatei): Application of isotherm and kinetic models. J Colloid and Interface Sci. 2002;342:533-539. DOI: 10.1016/j.jcis.2009.10.074.

[30] Gupta VK, Rostogi A. Biosorption of lead(II) from aqueous solutions by non-living algal biomass Oedogonium sp. and Nostoc sp. - A comparative study. Colloid Surface B. 2008;64:170-178. DOI: 10.1016/j.colsurfb.2008.01.019.

[31] Saeed A, Iqbal M, Akhta MW. Removal and recovery of lead(II) from single and multimetal $(\mathrm{Cd}, \mathrm{Cu}, \mathrm{Ni}$, $\mathrm{Zn}$ ) solutions by crop milling waste (black gram husk). J Hazard Mater B. 2005;117:65-73. DOI: 10.1016/j.jhazmat.2004.09.008.

[32] Cabral JP. Copper toxicity to five Parmalia lichens in vitro. Environ and Experiment Botany. 2003;49:237-250.

[33] Herrero R, Lodeiro P, Rey-Castro C, Vilariño T, Sastre de Vicente EM. Removal of inorganic mercury from aqueous solutions by biomass of the marine macroalga Cystoseira baccata. Water Res. 2005;39:3199-3210. DOI: $10.1016 /$ j.watres.2005.05.041.

[34] Kłos A, Rajfur M. Influence of hydrogen cations on kinetics and equilibria of heavy-metal sorption by algae - sorption of copper cations by the alga Palmaria palmate. J Appl Phycol. 2013;25(5):1387-1394. DOI: 10.1007/s10811-012-9970-6. 


\title{
WPŁYW SPOSOBU PREPAROWANIA PRÓBEK GLONÓW Spirogyra sp. NA ICH POJEMNOŚĆ SORPCYJNĄ
}

\author{
Samodzielna Katedra Biotechnologii i Biologii Molekularnej, Uniwersytet Opolski
}

\begin{abstract}
Abstrakt: Zbadano wpływ sposobu preparowania próbek na parametry sorpcji jonów cynku na glonach Spirogyra sp. Proces sorpcji $\mathrm{Zn}^{2+} \mathrm{z}$ roztworów soli tego analitu prowadzono $\mathrm{w}$ warunkach statycznych. Wyniki z przeprowadzonych badań wskazują, że sposób przygotowania próbek glonów do analiz (suszenie termiczne, liofilizacja, kondycjonowanie próbek w wodzie zdemineralizowanej) oraz czas przechowywania ma wpływ na ich pojemność sorpcyjną. Na podstawie przeprowadzonych badań kinetyki sorpcji tego metalu na żywych i preparowanych próbkach glonów stwierdzono, że stan równowagi zostaje osiągnięty po około 30 minutach. W warunkach prowadzenia eksperymentu $56 \%$ metali sorbowanych jest na glonach żywych w pierwszych 15 minutach. W próbkach glonów suszonych termicznie i liofilizowanych po 30 minutach trwania procesu zakumulowało się odpowiednio około 17 i $65 \%$ jonów cynku obecnych w roztworze. Stwierdzono, że kondycjonowanie próbek glonów przed procesem sorpcji w wodzie zdemineralizowanej podnosi jego wydajność. W celu wyznaczenia pojemności sorpcyjnej liofilizowanych glonów Spirogyra sp. zastosowano model izotermy Langmuira. Stwierdzono, że glony sorbują metale ciężkie proporcjonalnie do ich zawartości w roztworze, w którym zostały zanurzone. Wyznaczona z izotermy Langmuira pojemność sorpcyjna liofilizowanych glonów Spirogyra sp. względem cynku jest obarczona dużą niepewnością pomiarów. Stwierdzono wyraźny wpływ kationów wodorowych na stężenia miedzi w glonach i w roztworze w stanie równowagi.
\end{abstract}

Słowa kluczowe: cynk, glony Spirogyra sp., glony preparowane, kinetyka sorpcji, model izotermy Langmuira, pojemność sorpcyjna 